Original article

\title{
Kualitas post-thawing semen domba Merino dalam bahan pengencer berbasis susu skim-kuning telur yang ditambah isolat crude protein Tirosine Kinase
}

\section{Post-thawing quality of Merino ram semen in skim milk-egg yolk based diluent supplemented with crude protein Tyrosine Kinase isolate}

\author{
Krisna Widiantoro ${ }^{1}$, Sri Pantja Madyawati ${ }^{1 *}$, Sunaryo Hadi Warsito², Trilas Sardjito1, \\ Tatik Hernawati ${ }^{1}$, Indah Norma Triana ${ }^{1}$ \\ ${ }^{1}$ Division of Veterinary Reproduction, ${ }^{2}$ Division of Animal Husbandry \\ Faculty of Veterinary Medicine, Universitas Airlangga \\ ${ }^{*}$ Corresponding author, e-mail: sri-p-m@fkh.unair.ac.id \\ Open access under CC BY - SA license, DOI: 10.20473/ovz.v10i2.2021.39-45 \\ Received March 18 2021, Revised April 18 2021, Accepted July 282021 \\ Published online August 172021
}

\begin{abstract}
This study was conducted to determine the effect of crude protein tyrosine kinase (PTK) isolates supplementation into skim milk-egg yolk based diluent to maintain the quality of Merino ram spermatozoa. Four ejaculates of two Merino rams were divided into two groups for the control group (P0): Merino ram semen was diluted in skimmed milk-egg yolk based diluent, and the treatment group (P1): Merino ram semen was diluted in skim milk-egg yolk based diluent contained crude PTK $1,597 \mathrm{mg} / \mathrm{ml}$ diluent. All diluted semen was equilibrated for 2 hours at $5{ }^{\circ} \mathrm{C}$ and filled into $0.25 \mathrm{~mL}$ French straws. The filled straws were placed on steel racks (Cooltop, Minitube) held in liquid nitrogen vapour for 10 minutes at $-140{ }^{\circ} \mathrm{C}$, immersed immediately in liquid nitrogen at $196{ }^{\circ} \mathrm{C}$, and stored for 48 hours for later assessment. Post-thawed semen samples were evaluated for spermatozoa motility, viability, and morphological abnormality. The results showed that the spermatozoa motility of fresh semen of Merino ram was $82.5 \pm 2.89$, which was qualified for freezing. The post-thawing spermatozoa motility, viability, and morphological abnormalities of Merino ram in the P1 group were $34.11 \pm 3.26 \%, 38.00 \pm 3.00 \%$, and $12.89 \pm 4.54 \%$, respectively. It were higher $(p<0.05)$ than the control group of $24.44 \pm 2.9 \%, 26.67 \pm 3.32 \%$, and $21.11 \pm 3.02 \%$. It was concluded that the addition of crude PTK isolates of $1.597 \mathrm{mg} / \mathrm{ml} \mathrm{skim} \mathrm{milk-egg} \mathrm{yolk} \mathrm{diluent}$ improved the quality of post-thawed spermatozoa of Merino ram.
\end{abstract}

Keywords: abnormality, egg yolk-skim milk diluent, motility, protein tyrosine kinase, viability

\section{PENDAHULUAN}

Daging domba termasuk salah satu menu favorit masyarakat Indonesia, sehingga peningkatan populasi domba diharapkan dapat menjadi substitusi untuk memenuhi kebutuhan daging secara nasional (Suryadi et al., 2016). Namun kenyataannya produksi daging domba di Indonesia justru menurun dari tahun 2018 sampai dengan tahun 2020. Produksi daging domba secara nasional adalah $82.274,38$ ton pada tahun 2018, turun menjadi $70.072,93$ ton tahun 2019, dan turun lagi menjadi 66.943,34 ton pada tahun 2020 (BPS, 2020). Salah satu alternatif usaha untuk meningkatkan jumlah pasokan daging domba adalah dengan pengembangan jenis domba unggulan, yaitu domba Merino. Domba Merino adalah ternak ruminansia kecil yang memiliki kondisi fisik lebih berat dan besar dibandingkan dombadomba lain yang ada di Indonesia, serta 
persentase karkas yang cukup tinggi sebagai ternak pedaging (Mortimer et al., 2017).

Peningkatan populasi domba Merino di Indonesia dapat dilakukan dengan teknik inseminasi buatan. Program inseminasi buatan dengan menggunakan semen yang berkualitas baik merupakan solusi dalam mengatasi rendahnya produktifitas ternak. Manfaat maksimum inseminasi buatan dapat diperoleh apabila digunakan semen beku karena dapat disimpan dalam jangka waktu yang panjang dan dapat disebarkan kedalam jangkauan wilayah yang luas (Kumar dan Naqvi, 2014). Semen beku yang berkualitas tinggi membutuhkan protokol pengolahan yang baik, diantaranya bahan pengencer semen untuk meningkatkan volume semen dan mempertahankan kualitas spermatozoa selama proses pendinginan, pembekuan, hingga setelah thawing. Namun sebagaimana semen domba yang lain, semen domba Merino rentan terhadap berbagai kerusakan selama proses pembekuan dan pencairan kembali. Berbagai kerusakan tersebut meliputi kerusakan ultrastruktural, biokimia dan fungsional. Biasanya tidak lebih dari 50\% spermatozoa bertahan dari kriopreservasi. Sisa spermatozoa yang masih hidup juga mengalami kerusakan pada organel dan membran spermatozoa, sehingga menghasilkan tingkat kesuburan yang rendah. Kerusakan spermatozoa selama freezing-thawing, dapat disebabkan oleh faktor-faktor thermal shock, pembentukan kristal es, dehidrasi, peningkatan konsentrasi garam dan osmotic shock (Galarza et al., 2019). Bahan suplementasi bisa ditambahkan untuk meningkatkan kapasitas bahan pengencer sehingga dapat meminimalkan kerusakankerusakan spermatozoa akibat proses pembekuan, salah satunya adalah protein tirosin kinase (PTK). Penelitian sebelumnya pada semen sapi FH menunjukkan bahwa penambahan PTK pada dosis $100 \mu \mathrm{g} / \mathrm{ml} \mathrm{ke}$ dalam medium pengencer semen beku berbasis susu skim-kuning telur dapat meningkatkan motilitas spermatozoa, persentase spermatozoa hidup dan persentase integritas membran sesudah pembekuan (Madyawati, 2008).

Tirosin kinase termasuk dalam kelompok protein yang salah satu fungsinya menstabilkan ikatan kovalen penyusun protein membran sehingga bila disuplementasikan ke dalam medium pengencer diharapkan dapat mencegah putusnya ikatan kovalen membran spermatozoa. Tirosin kinase dapat berikatan dengan reseptor tirosin kinase yang berada di membran plasma spermatozoa kemudian akan mengaktifkan signal tranduksi sampai terjadi proses fosforilasi tirosin kinase yang dapat menyebabkan hiperaktivitas dan peningkatan motilitas spermatozoa (Metibemu et al., 2019). Penelitian ini dilakukan untuk mengetahui pengaruh isolat crude PTK yang ditambahkan kedalam pengencer berbasis susu skim-kuning telur untuk mempertahankan kualitas spermatozoa domba Merino.

\section{MATERI DAN METODE}

Penelitian dilakukan di Taman Ternak Pendidikan Fakultas Kedokteran Hewan Universitas Airlangga, desa Tanjung, kecamatan Kedamean, kabupaten Gresik. Pejantan domba Merino yang digunakan dua ekor dengan umur 3-4 tahun dan bobot badan 50-70 kg. Sampel semen domba Merino dikoleksi dengan vagina buatan, sebanyak dua kali dalam seminggu. Empat ejakulat yang diperoleh masing-masing dibagi dua sehingga masing-masing kelompok terdiri atas empat kali penampungan semen. Semen dievaluasi secara makroskopis meliputi volume, warna, bau, derajat keasaman $(\mathrm{pH})$ dan konsistensi, serta secara mikroskopis meliputi gerakan massa, motilitas progresif, skor kecepatan, konsentrasi, viabilitas (Susilowati et al., 2019), dan abnormalitas morfologi spermatozoa (Afiati et al., 2015).

Isolat crude PTK diperoleh dari beberapa peneliti sebelumnya. Identifikasi, karakterisasi dan isolasi PTK hasil isolasi spermatozoa sapi FH dilakukan dengan metode SDS-PAGE (Wardani et al., 2017; Nawangwulan et al., 2018) yang dikonfirmasi dengan metode Dot Blot dan dilanjutkan dengan Western Blot menggunakan monoklonal antibodi tirosin kinase, serta uji aktifitas tirosin kinase hasil isolasi spermatozoa sapi FH melalui penentuan kondisi optimumnya (Madyawati, 2008; Madyawati et al., 2017). 


\section{Diluter kuning telur - susu skim}

Susu bubuk skim (Merck 115338) 10 gram dilarutkan dalam $100 \mathrm{~mL}$ akuades, dipanaskan hingga $92-95{ }^{\circ} \mathrm{C}$ selama 10 menit, lalu didinginkan hingga $37{ }^{\circ} \mathrm{C}$. Kuning telur (dari telur ayam untuk penggunaan laboratorium) 5 $\mathrm{mL}$ ditambah dengan larutan susu skim $100 \mathrm{~mL}$, ditambah penisilin dan streptomisin masingmasing $1.000 \quad \mathrm{IU} / \mathrm{mL}$ dan $0,1 \mathrm{mg} / \mathrm{mL}$ (Susilowati et al., 2021). Campuran tersebut dibagi menjadi dua bagian yang sama untuk kelompok kontrol (P0, tanpa penambahan isolat crude PTK), dan kelompok perlakuan T1 yang ditambah isolat crude PTK $1,597 \mathrm{mg} / \mathrm{ml}$ pengencer.

\section{Pembekuan semen}

Masing-masing diluter kelompok tersebut dibagi menjadi dua bagian yang sama. Bagian pertama ditambah semen untuk mendapatkan konsentrasi 480 juta spermatozoa/mL. Bagian kedua ditambah gliserol hingga konsentrasi $16 \%$, kemudian ditambahkan perlahan-lahan ke dalam campuran pertama sehingga diperoleh konsentrasi 240 juta spermatozoa $/ \mathrm{mL}$. Selanjutnya, semua campuran semen tersebut diekuilibrasi pada $5^{\circ} \mathrm{C}$ selama satu jam. Setelah itu, campuran semen dikemas dalam French straw $0,25 \mathrm{ml}$ sehingga masing-masing straw berisi 60 juta spermatozoa. Straw yang telah diisi dan disegel ditempatkan pada Cooltop (Minitube) dalam uap nitrogen cair $\left(-140{ }^{\circ} \mathrm{C}\right)$ selama 10 menit, kemudian segera disimpan dalam nitrogen cair $\left(-196{ }^{\circ} \mathrm{C}\right)$. Sampel straw masing-masing kelompok dicairkan kembali (thawing) dalam air steril pada suhu $37{ }^{\circ} \mathrm{C}$ selama 30 detik (Susilowati et al., 2021) untuk evaluasi kualitas semen post-thawing dengan empat ulangan.

\section{Pemeriksaan viabilitas dan abnormalitas morfologi spermatozoa}

Sampel diteteskan pada gelas obyek, dicampur homogen dengan eosin nigrosin sama banyak, dibuat preparat ulas dan dikeringkan di atas api. Viabilitas spermatozoa diperiksa pada perbesaran 400x di bawah mikroskop cahaya (Olympus BX-53). Kepala spermatozoa hidup tampak bening terang tidak menyerap zat warna, sedangkan spermatozoa yang mati berwarna kemerahan menyerap zat warna (Susilowati et al., 2020).

Pengamatan abnormalitas morfologi spermatozoa dilakukan menggunakan mikroskop cahaya dengan perbesaran 400 kali pada 100 sel spermatozoa. Abnormalitas morfologi spermatozoa yang diamati pada bagian kepala, leher, dan ekor spermatozoa (Afiati et al., 2015).

\section{Pemeriksaan motilitas spermatozoa}

Sebanyak $10 \mu \mathrm{L}$ sampel ditambah $1 \mathrm{~mL}$ larutan garam fisiologis, dihomogenkan dan diteteskan pada gelas obyek, kemudian ditutup dengan gelas penutup. Jumlah motilitas progresif dihitung pada 100 spermatozoa dengan perbesaran 400X di bawah mikroskop cahaya (Susilowati et al., 2020).

\section{HASIL}

Sampel semen segar domba Merino pada penelitian ini berwarna putih-krem, bau khas semen domba Merino (prengus), konsistensi sedang, gerakan massa +2 (kualifikasi baik, terlihat gelombang-gelombang kecil, tipis, jarang, dan bergerak lambat) sampai dengan +3 (kualifikasi sangat baik, terlihat gelombanggelombang besar, tebal, banyak, dan aktif bergerak), skor kecepatan tiga, dan konsistensi sedang. Volume semen 2,15 $\pm 0,26 \mathrm{~mL}, \mathrm{pH}$ $6,55 \pm 0,244$, konsentrasi $2050.75 \pm 166.75$ juta/mL, rata-rata gerakan massa $2,75 \pm 0,5$ (skala 1-4), dan motilitas $82,5 \pm 2,89 \%$.

Tabel 1 Motilitas, viabilitas, dan abnormalitas morfologi post thawing semen domba Merino

\begin{tabular}{cccc}
\hline & motilitas & viabilitas & abnormalitas \\
\hline P0 & $24,44 \pm 2,97^{\mathrm{b}}$ & $26,67 \pm 3,32^{\mathrm{b}}$ & $21,11 \pm 3,02^{\mathrm{b}}$ \\
P1 & $34,11 \pm 3,26^{\mathrm{a}}$ & $38,00 \pm 3,00^{\mathrm{a}}$ & $12,89 \pm 4,54^{\mathrm{a}}$ \\
\hline
\end{tabular}

$\mathrm{P} 0=$ semen segar domba Merino diencerkan dalam diluter susu skim-kuning telur; $\mathrm{P} 1=$ semen segar domba Merino diencerkan dalam diluter susu skim-kuning telur yang mengandung crude PTK $1,597 \mathrm{mg} / \mathrm{mL}$. Superskrip yang berbeda dalam satu kolom menunjukkan perbedaan nyata $(\mathrm{p}<0,05)$. 
Hasil pemeriksaan motilitas, viabilitas, abnormalitas morfologi post-thawing spermatozoa domba Merino pada kelompok perlakuan (P1) masing-masing lebih tinggi ( $p$ $<0,05)$ dibandingkan pada kelompok kontrol (Tabel 1).

\section{DISKUSI}

Warna, bau, konsistensi, pH, dan gerakan massa semen segar domba Merino dalam penelitian ini relatif sama dengan penelitianpenelitian sebelumnya, dengan rata-rata volume ejakulat yang diperoleh adalah $2,15 \pm 0,26 \mathrm{ml}$. Konsentrasi tersebut lebih tinggi dibandingkan volume ejakulat domba lokal yaitu $0,4-0,85 \mathrm{~mL}$ (Alvionita et al., 2015), domba Garut 1,94 mL dan domba Merino 1-1,4 mL (Fachry et al., 2014), namun lebih rendah dibandingkan domba ekor gemuk 2,42 mL (Isnaini et al., 2021) dan domba Merino 3,2-5 mL (Saputro et al., 2016).

\section{Motilitas spermatozoa}

Motilitas semen segar domba Merino pada penelitian ini $(82,5 \pm 2,89 \%)$ memenuhi syarat untuk diproses sebagai semen beku, karena lebih dari 70\% (SNI 4869.3, 2014). Namun, proses pembekuan pada kelompok kontrol (P0), tanpa penambahan isolat PTK, menyebabkan motilitas spermatozoa tinggal $24,44 \pm 2,97 \%$ (kolom pertama Tabel 2). Selama proses freezethawing, terjadi reorganisasi fosfolipid membran spermatozoa, mengubah interaksi lipid-protein, lipid-karbohidrat, dan proteinkarbohidrat, yang menyebabkan perubahan aktivitas membran (Peris-Frau et al., 2020). Membran plasma melindungi organel spermatozoa dan bertindak sebagai filter untuk transpor transmembran. Oleh karena itu, integritas membran plasma penting untuk kelangsungan hidup dan motilitas spermatozoa (Pereira et al., 2017). Selama proses pembekuan dihasilkan reactive oxygen species (ROS) yang berlebihan yang menyebabkan perubahan protein, lipid, dan karbohidrat pada membran spermatozoa (Dutta et al., 2019). ROS akan mengurangi ikatan disulfida antara protein membran dan peroksidasi fosfolipid membran dan modifikasi glikokaliks spermatozoa.
Akibatnya, membran spermatozoa menjadi rapuh dan kehilangan semi permeabilitas. ROS yang lebih tinggi merusak beberapa protein aksonemal dan mitokondria, yang mengakibatkan hilangnya motilitas spermatozoa (Peris-Frau et al., 2020).

Adanya kandungan PTK 1,597 mg/mL pengencer susu skim-kuning telur menyebabkan peningkatan nyata (p <0,05) motilitas spermatozoa dari 24,44 $\pm 2,97$ menjadi $34,11 \pm$ $3,26 \%$. Motilitas spermatozoa sangat tergantung pada beberapa jalur metabolisme dan mekanisme pengaturannya. Jalur kalsium maupun jalur protein kinase yang bergantung pada cAMP merupakan faktor penting motilitas spermatozoa (Pereira et al., 2017). Protein kinase A (PKA) mengaktifkan tirosin kinase untuk memicu kaskade untuk terjadinya motilitas spermatozoa (Pereira et al., 2017). Fosforilasi pada protein-tirosin kinase berperan pada pergerakan aksonema, sebagai bagian dari kaskade pensinyalan dalam regulasi motilitas spermatozoa tersebut (Ijiri et al., 2012). Meskipun kandungan crude PTK 1,597 mg/mL pengencer susu skim-kuning telur dapat menyebabkan peningkatan nyata motilitas spermatozoa, dari $24,44 \pm 2,97$ menjadi $34,11 \pm$ $3,26 \%$, namun persentase motilitas tersebut masih kurang dari $40 \%$ sehingga belum memenuhi syarat untuk inseminasi buatan (SNI 4869.3, 2014). Perlu dilakukan penelitian lebih lanjut untuk mendapatkan persentase motilitas spermatozoa yang memenuhi kualifikasi tersebut.

\section{Viabilitas spermatozoa post thawing}

Penambahan crude PTK $1,597 \mathrm{mg} / \mathrm{mL}$ pengencer berbasis susu skim-kuning telur menyebabkan peningkatan nyata $(p<0,05)$ viabilitas spermatozoa dari 26,67 $\pm 3,32$ menjadi 38,00 $\pm 3,00$. Rendahnya viabilitas spermatozoa merupakan salah satu penyebab infertilitas pada pejantan. Protein kinase dan fosfatase memediasi proses modifikasi pascatranslasi dalam menentukan viabilitas spermatozoa (Brohi dan Huo, 2017). Ada hubungan antara integritas membran dengan posforilasi PTK. Pada spermatozoa hidup, ionofor memicu beberapa kaskade intraseluler, yang mengarah pada defosforilasi protein- 
tirosin untuk menginduksi eksositosis akrosom, yang diproduksi secara spontan selama kapasitasi (Ruiz-Díaz et al., 2020).

\section{Abnormalitas spermatozoa post thawing}

Kandungan crude PTK $1,597 \mathrm{mg} / \mathrm{mL}$ pengencer susu skim-kuning telur menyebabkan penurunan nyata (p <0,05) persentase abnormalitas morfologi spermatozoa dari 21,11 $\pm 3,02$ menjadi $12,89 \pm 4,54$. Morfologi spermatozoa yang normal merupakan salah satu parameter semen paling informatif yang digunakan untuk fertilitas (Pereira et al., 2017). Abnormalitas merupakan salah satu indikator dalam menentukan kualitas spermatozoa, karena struktur sel yang abnormal dapat menyebabkan gangguan dan hambatan pada saat fertilisasi, lebih jauh menyebabkan rendahnya angka implantasi maupun kebuntingan. Abnormalitas morfologi selalu ditemukan dalam setiap ejakulasi, namun mempunyai dampak yang berbeda terhadap fertilitas. Beberapa abnormalitas tertentu dapat menghambat pembuahan, sementara yang lain, seperti kelainan kepala spermatozoa pear shape dapat mengganggu perkembangan embrio (Afiati et al. 2015).

Intensitas fosforilasi PTK lebih tinggi selama kapasitasi pada kelompok normospermia dibandingkan kelompok teratospermia (Sepideh et al., 2009). Terdapat korelasi antara berbagai kelainan morfologi spermatozoa dengan stres oksidatif spermatozoa pada pria infertil dan fertil. Pengaruh potensi reduksi dan fragmentasi DNA spermatozoa (diukur dengan dispersi kromatin spermatozoa) terhadap anomali morfologi spermatozoa pada pria infertil dan fertil (Dutta et al., 2019). Selain keterlibatan defek gen tertentu, setiap kelainan morfologi spermatozoa dapat dipengaruhi oleh PKA mengaktifkan tirosin kinase spermatozoa (Pereira et al., 2017).

PKA memfosforilasi residu serin dan tirosin, yang juga dapat mengaktifkan PTK. Selanjutnya, PTK memicu fosforilasi residu tirosin dalam selubung fibrosa di sekitar aksonem dan sitoskeleton flagel spermatozoa (Dutta et al., 2019). Keluarga gen penyandi PTK menghasilkan pola khas fosforilasi tirosin protein yang diinduksi kapasitasi sedikit dimodifikasi pada spermatozoa. PTK memainkan peran penting dalam pembentukan kepala dan akrosom spermatozoa (Luo et al., 2012).

\section{KESIMPULAN}

Penambahan isolat crude PTK dengan konsentrasi $1,597 \mathrm{mg} / \mathrm{mL}$ bahan pengencer berbasis susu skim-kuning telur dapat meningkatkan kualitas spermatozoa post thawing domba Merino.

\section{DAFTAR PUSTAKA}

Afiati F, Yulnawati Y, Riyadi M, Arifiantini RI. 2015. Abnormalitas spermatozoa domba dengan frekuensi penampungan berbeda. Pros Sem Nas Masy Biodiv Indo. 1: 930934.

Alvionita C, Rasad SD, Solihati N. 2015. Kualitas semen domba lokal pada berbagai kelompok umur. Student e-journals 4:1-9.

BPS (Badan Pusat Statistik). 2020. Produksi Daging Domba menurut Provinsi (Ton), 2018-2020.

https://www.bps.go.id/indicator/24/483/1/p roduksi-daging-domba-menurutprovinsi.html [Diakses 3 Juli 2021]

Brohi RD, Huo L-J. 2017. Posttranslational Modifications in Spermatozoa and Effects on Male Fertility and Sperm Viability. OMICS. 21: 245-56.

Dutta S, Majzoub A, Agarwal A. 2019. Oxidative stress and sperm function: $\mathrm{A}$ systematic review on evaluation and management. Arab J Urol. 17: 87-97.

Fachry F, Sunarso A, Sardjito T, Wurlina W, Srianto P, Suprayogi TW. 2014. Evaluasi semen segar Domba Merino untuk produksi semen beku di Taman Ternak Pendidikan FKH Unair. Ovozoa 3: 192-7.

Galarza DA, López-Sebastián A, Woelders H, Blesbois E, Santiago-Moreno J. 2019. Twostep accelerating freezing protocol yields a better motility, membranes and DNA integrities of thawed ram sperm than threesteps freezing protocols. Cryobiology 91: 84-9.

Ijiri TW, Mahbub Hasan AK, Sato K. 2012. Protein-tyrosine kinase signaling in the 
biological functions associated with sperm. J Signal Transduct. 2012:181560.

Isnaini $\mathrm{N}$, Wahjuningsih $\mathrm{S}$, Falah $\mathrm{MM}$, Fajarrofa A, Harsi T, Sukmawati E. 2021. Seasonal variations on semen characteristics of Fat-Tailed and Garut Rams under tropical conditions. J Ked Hewan 15: 11-4.

Luo J, Gupta V, Kern B, Tash JS, Sanchez G, Blanco G, Kinsey WH. 2012. Role of FYN Kinase in Spermatogenesis: Defects Characteristic of Fyn-Null Sperm in Mice, Biol Reprod. 86: 1-8.

Kumar D, Naqvi SMK. 2014. Effect of time and depth of insemination on fertility of Bharat Merino ram inseminated trans-cervical with frozen-thawed semen. J Anim Sci Technol. 56: 8 .

Madyawati SP, Sardjito T, Srianto P, Safitri E. 2017. Characterization of Tyrosine Kinase protein in spermatozoa plasma membrane of Merino ram. Int J Chemtech Res. 10: 627.

Madyawati SP. 2008. Suplementasi tirosin kinase spermatozoa sapi Friesian Holstein (FH) terhadap kualitas semen beku. Disertasi, Universitas Airlangga.

Metibemu DS, Akinloye OA, Akamo AJ, Ojo DA, Okeowo OT, Omotuyi IO. 2019. Exploring receptor tyrosine kinasesinhibitors in Cancer treatments. Egypt $\mathrm{J}$ Med Hum Genet. 20: 35.

Mortimer SI, Hatcher S, Fogarty NM, van der Werf JHJ, Brown DJ, Swan AA, Jacob RH, Geesink GH, Hopkins DL, Edwards JEH, Ponnampalam EN, Pearce KL, Pethick DW. 2017. Genetic correlations between wool traits and carcass traits in Merino ram. J Anim Sci. 95: 2385-98.

Nawangwulan T, Madyawati SP, Plumeriastuti H. 2018. Profile of Protein Tyrosine Kinase in Seminal Plasma of Merino Ram Using Technique of Sodium Dodecyl Sulphate Polyacrilamide Gel Electrophoresis. Int J Chemtech Res. 11: 214-8.

Pereira R, Sá R, Barros A, Sousa M. 2017. Major regulatory mechanisms involved in sperm motility. Asian J Androl. 19: 5-14.

Peris-Frau P, Soler AJ, Iniesta-Cuerda $M$, Martín-Maestro A, Sánchez-Ajofrín I, Medina-Chávez DA, Fernández-Santos
MR, García-Álvarez O, Maroto-Morales A, Montoro V, Garde JJ. 2020. Sperm Cryodamage in Ruminants: Understanding the Molecular Changes Induced by the Cryopreservation Process to Optimize Sperm Quality. Int J Mol Sci. 21: 2781.

Ruiz-Díaz S, Grande-Pérez S, Arce-López S, Tamargo C, Olegario Hidalgo C, PérezCerezales S. 2020. Changes in the Cellular Distribution of Tyrosine Phosphorylation and Its Relationship with the Acrosomal Exocytosis and Plasma Membrane Integrity during In Vitro Capacitation of Frozen/Thawed Bull Spermatozoa. Int J Mol Sci. 21: 2725.

Saputro AL, Hermadi HA, Sosiawati SM. 2016. Kualitas Spermatozoa Domba Merino pada Sisi Anoda Hasil Pemisahan dengan Teknik ESS (Electric Separating Sperm). Vet Med 9: 61-6.

Sepideh J, Reza SM, Mahdi AM, Azadeh EH, Naser A, Niknam L, Lima A, Ardekani AM. 2009. Tyrosine phosphorylation pattern in sperm proteins isolated from normospermic and teratospermic men. J Reprod Infertil. 10: 185-91.

SNI (Standar Nasional Indonesia) 4869.3. 2014 Semen beku, Bagian 3 Kambing dan domba. Jakarta; 2014. Diakses 30 Juli 2021.

Suryadi D, Rahayu S, Firmansyah C, Kuswaryan S. 2016. Preferensi Konsumen terhadap Daging Domba di Jawa Barat. Sosiohumaniora 18: $27-33$.

Susilowati S, Sardjito T, Mustofa I, Widodo OS, Kurnijasanti R. 2021. Effect of green tea extract in extender of Simmental bull semen on pregnancy rate of recipients. Anim Biosci. 34: 198-204.

Susilowati S, Triana IN, Sardjito T, Suprayogi TW, Wurlina W, Mustofa I. 2020. Effect of Simmental bull seminal plasma protein in egg yolk-citrate extender on Kacang buck semen fertility. Cryobiology 97: 20-7.

Susilowati S, Triana IN, Wurlina W, Arimbi A, Srianto P, Mustofa I. 2019. Addition of Larginine in skim milk extender maintains goat spermatozoa quality in chilled temperature for five days. Vet World. 12: 1784-9. 
Wardani VC, Madyawati SP, Hastutiek P. 2017. Profile of Crude Protein Tyrosine Kinase on Plasma Membrane of Merino Ram Spermatozoa Using the Method of SDS-
Page (Sodium Dodecyl SulphatePolyacrilamide Gel Electrophoresis). KnE Life Sciences / The Veterinary Medicine International Conference (VMIC): 197-20. 